\title{
Pregnancy block in laboratory mice as a function of male social status
}

\author{
U. W. Huck* \\ Department of Biology, Swarthmore College, Swarthmore, Pennsylvania 19081, U.S.A.
}

\begin{abstract}
Summary. When female laboratory mice mated to dominant or subordinate stud males were exposed 1 day later to the original stud, a strange dominant male or a strange subordinate, strange dominant males induced more pregnancy block than did strange subordinates. However, the social status of the stud male did not significantly alter the risk of pregnancy block after exposure to strange males.
\end{abstract}

\section{Introduction}

Bruce (1960) first demonstrated that the presence of a strange male mouse blocked the pregnancy of recently impregnated females in the laboratory. Pregnancy blockage was followed by a return to oestrus $4-5$ days after the original mating, and fertile mating with the second male typically occurred. Subsequent investigations of the generality of the 'Bruce Effect' indicated that it is exhibited under laboratory conditions in wild Mus musculus (Chipman \& Fox, 1966) and in several species of mice and voles (Richmond \& Stehn, 1976). Apparently pregnancy block and the induction of ovulation in non-pregnant females are encompassed by the same system (Bronson, 1979); both phenomena result from the release of gonadotrophins after exposure to a strange male (Hoppe \& Whitten, 1972).

The male urinary pheromones which induce these effects are androgen-dependent (Bronson \& Whitten, 1968) and are not present in castrated mice (Bruce, 1965). Social subordination suppresses gonadal function in male laboratory mice (Bronson, 1973), inhibits scent marking (Desjardins, Maruniak \& Bronson, 1973), and suppresses the ability of male urine to accelerate the onset of puberty in females (Lombardi \& Vandenbergh, 1977). In the present study we tested the hypothesis that dominant male laboratory mice would be more effective in inducing pregnancy blockage than would subordinate males. We also tested the possibility that pregnancy block would be less likely to occur in females impregnated by dominant males than in those impregnated by subordinates.

\section{Materials and Methods}

\section{Animals}

The mice were Swiss-Webster albinos randomly bred at Swarthmore College. Females were housed singly in plastic cages $(29 \times 18 \times 13 \mathrm{~cm})$ with a wire-mesh top and sawdust bedding. All females were adult virgins, $75-93$ days of age (mean $=79.6$ days).

Social rank was established by pairing the same two males in a neutral arena for $10 \mathrm{~min}$ on

* Present address: Department of Biology, Princeton University, Princeton, New Jersey 08544, U.S.A. 
each of 10-15 consecutive days. During each encounter, frequencies of agonistic behaviour were recorded. An animal was classified as dominant if its daily chase-attack score was significantly higher $\left(\chi^{2}\right.$ test) than that of the other member of the pair. Only pairs displaying stable dominance-subordinance relationships during the last 10 ranking tests were used.

Tests

A total of 390 females were assigned to 1 of 8 experimental groups (Table 1). Females in 4 of the groups were paired with a dominant stud male and those in the other 4 groups with a subordinate male. Females with vaginal plugs were separated from the stud male and placed into individual plastic cages. One day later, the original stud male, or a strange dominant or subordinate male of a body weight similar to that of the stud $( \pm 2.5 \mathrm{~g})$ was placed into the female's cage for $48 \mathrm{~h}$, separated from her by a wire-mesh partition. A fourth group of females remained undisturbed following their exposure to a stud male. After these treatments, the females were left undisturbed for 3 weeks and the number of litters was recorded.

\section{Results}

Log likelihood ratio tests (Bickel \& Doksum, 1977) were used to evaluate the data statistically (Table 1). Re-exposure to stud males did not significantly reduce the proportion of females with successful pregnancies (Treatments 1 and 5 compared with 2 and $6 ; \chi_{(1)}^{2}=0.51$ ). Pregnancy success was significantly reduced in females exposed to strange dominant males (Treatments 2 and 6 compared with 3 and $7 ; \chi_{(1)}^{2}=35.15, P<0.005$ ) as well as to strange subordinates (Treatments 2 and 6 compared with 4 and $8 ; \chi_{(1)}^{2}=7.36, P<0.01$ ). A comparison of the ability of dominant and subordinate males to block pregnancy indicated that the former were significantly more effective (Treatments 3 and 7 compared with 4 and $8 ; \chi_{(1)}^{2}=10.88, P<$ 0.005 ).

Table 1. Pregnancy success in laboratory mice under various experimental conditions

\begin{tabular}{|c|c|c|c|c|c|}
\hline \multirow[b]{2}{*}{ Group } & \multicolumn{2}{|c|}{ Conditions of test } & \multirow{2}{*}{$\begin{array}{l}\text { Total no. } \\
\text { of females }\end{array}$} & \multirow{2}{*}{$\begin{array}{c}\text { No. of } \\
\text { successful } \\
\text { pregnancies }\end{array}$} & \multirow{2}{*}{$\begin{array}{c}\% \\
\text { Successful } \\
\text { pregnancies }\end{array}$} \\
\hline & Stud male & Second male & & & \\
\hline 1 & Dominant & None & 45 & 42 & $93 \cdot 3$ \\
\hline 2 & Dominant & Stud & 40 & 35 & $87 \cdot 5$ \\
\hline 3 & Dominant & Strange dominant & 40 & 19 & 47.5 \\
\hline 4 & Dominant & Strange subordinate & 45 & 32 & $71 \cdot 1$ \\
\hline 5 & Subordinate & None & 45 & 37 & $82 \cdot 2$ \\
\hline 6 & Subordinate & Stud & 40 & 31 & $77 \cdot 5$ \\
\hline 7 & Subordinate & Strange dominant & 45 & 13 & $28 \cdot 9$ \\
\hline 8 & Subordinate & Strange subordinate & 40 & 24 & $60 \cdot 0$ \\
\hline
\end{tabular}

When their scores were adjusted for pregnancy rates of stud males, females impregnated by subordinate males did not run a significantly higher risk of pregnancy block when exposed to strange males than did females impregnated by dominant males (Treatments 3 and 4 compared with 7 and $\left.8 ; \chi_{(1)}^{2}=3 \cdot 38\right)$. There was no significant difference in the ability of dominant and subordinate stud males to initiate pregnancy (Treatments 1 and 2 compared with 5 and 6; $\left.\chi_{(1)}^{2}=0 \cdot 90\right)$.

\section{Discussion}

These results support and extend earlier reports of pregnancy block in recently mated female rodents after exposure to a strange male. However, in the present study the magnitude of this 
effect depended on the strange male's social status. Dominant males blocked pregnancy more effectively than did social subordinates. As in earlier studies, pregnancy block was not induced by re-exposure to stud males.

For a male the selective advantages of inducing pregnancy block are apparent. Pregnancy block decreases the reproductive fitness of other males in the population relative to his own and causes the female to return to oestrus, thus increasing the likelihood that he will mate with her (Trivers, 1972; Wilson, 1975). In contrast, selective advantages of pregnancy block for females have been more difficult to identify (Bronson, 1979).

Dawkins (1976) suggested that pregnancy block may be advantageous for a female who has been deserted by her mate as well as for the new mate. Although she forfeits her initial investment, the female benefits from remating quickly with a male who will presumably provide parental care. And, by inducing pregnancy block, the new male avoids parental investment in another male's offspring and gains a mating. However, this hypothesis does not account for the evolution of pregnancy block in species where males provide little or no post-copulatory parental investment (e.g. Mus and most other mammals) (Schwagmeyer, 1979).

A more compelling advantage of pregnancy block was suggested by the results of recent studies of infanticidal behaviour in male rodents towards unrelated young (Mallory \& Brooks, 1978; Labov, 1980; Webster, Gartshore \& Brooks, 1981). If the potential for male infanticide is high, pregnancy block may be advantageous for a female because the loss of a fertilized egg or newly implanted embryo would reduce her overall reproductive fitness far less than would the loss of a newborn litter (Schwagmeyer, 1979).

Insofar as (a) not all males kill unrelated young (Labov, 1980; Webster et al., 1981) and (b) pregnancy block represents a relatively small but nonetheless significant loss of reproductive fitness, it would be selectively advantageous for females to discriminate between potentially infanticidal and non-infanticidal males. The finding that strange subordinate males blocked pregnancy less frequently than did dominants suggests that the former may also be less likely to engage in infanticide, and the validity of this premise has been shown for laboratory mice (Huck, Soltis \& Coopersmith, 1982).

Pregnancy block may also play a role in mate selection. If dominant males bear genes that produce fitter offspring and/or enable them to gain and defend resources, females that are differentially attracted to and mate with dominants may have a selective advantage over less discriminating females. If pregnancy block has evolved as a strategy by females to increase the likelihood that their offspring will be sired by dominant males (Schwagmeyer, 1979), two predictions may be made. (1) Dominant males should be more effective in blocking pregnancy than subordinates. And (2), pregnancy block should be less likely to occur in females impregnated by dominant males than in females impregnated by subordinates. The results of this study are consistent with the first prediction but equivocal with regard to the second. Dominant males induced more pregnancy block than subordinates but the social status of stud males did not significantly alter the susceptibility of females to pregnancy blockage although the effect was in the predicted direction.

The physiological mechanisms underlying pregnancy block have been elucidated and a number of arguments for the adaptive significance of this phenomenon have been advanced. However, it has not been established whether the Bruce effect is a significant factor in the reproductive biology of wild populations or merely a laboratory artefact as Bronson (1979) has suggested.

\section{References}

Bickel, P.J. \& Doksum, K.A. (1977) Mathematical Statistics: Basic Ideas and Selected Topics. HoldenDay, San Francisco.

Bronson, F.H. (1973) Establishment of social rank among grouped male mice: relative effects on circulating FSH, LH, and corticosterone. Physiol. Behav. 10, 947-951.

Bronson, F.H. (1979) The reproductive ecology of the house mouse. Q. Rev. Biol. 54, 265-299.

Bronson, F.H. \& Whitten, W.K. (1968) Oestrus- 
accelerating pheromone of mice: assay, androgendependency, and presence in bladder urine. $J$. Reprod. Fert. 15, 131-154.

Bruce, H.M. (1960) A block to pregnancy in the mouse caused by proximity of strange males. J. Reprod. Fert. 1, 96-103.

Bruce, H.M. (1965) Effect of castration on the reproductive pheromones of male mice. $J$. Reprod. Fert. 10, 141-143.

Chipman, R.K. \& Fox, K.A. (1966) Oestrous synchronization and pregnancy blocking in wild house mice (Mus musculus). J. Reprod. Fert. 12, 233-236.

Dawkins, R. (1976) The Selfish Gene. Oxford University Press, New York.

Desjardins, C., Maruniak, J.A. \& Bronson, F.H. (1973) Social rank in house mice: differentiation revealed by ultraviolet visualization of urinary marking patterns. Science, N.Y. 182, 939-941.

Hoppe, P.C. \& Whitten, W.K. (1972) Pregnancy block: imitation by administered gonadotropin. Biol. Reprod. 7, 254-259.

Huck, U.W., Soltis, R.L. \& Coopersmith, C.B. (1982) Infanticide in male laboratory mice: effects of social status, prior sexual experience, and basis for discrimination between related and unrelated young. Anim. Behav. (in press).

Labov, J.B. (1980) Factors influencing infanticidal behavior in wild male house mice (Mus musculus). Behav. Ecol. Sociobiol. 6, 297-303.
Lombardi, J.R. \& Vandenbergh, J.G. (1977) Pheromonally induced sexual maturation in females: regulation by the social environment of the male. Science, N.Y. 196, 545-546.

Mallory, F.F. \& Brooks, R.J. (1978) Infanticide and other reproductive strategies in the collared lemming, Dicrostonyx groenlandicus. Nature, Lond. 273, 144-146.

Richmond, M. \& Stehn, R. (1976) Olfaction and reproductive behavior in microtine rodents. In Mammalian Olfaction, Reproductive Processes, and Behavior, pp. 198-217. Ed. R. L. Doty. Academic Press, New York.

Schwagmeyer, P.L. (1979) The Bruce effect: an evaluation of male/female advantages. Am. Nat. 114 , 932, 938.

Trivers, R.L. (1972) Parental investment and sexual selection. In Sexual Selection and the Descent of Man, 1871-1971, pp. 136-179. Ed. B. Campbell. Aldine, Chicago.

Webster, A.B., Gartshore, R.G. \& Brooks, R.J. (1981) Infanticide in the meadow vole, Microtus pennsylvanicus: significance in relation to social system and population cycling. Behav. Neur. Biol. 31, 342-347.

Wilson, E.O. (1975) Sociobiology: the New Synthesis. Harvard University Press, Cambridge.

Received 17 November 1981 